\title{
Importance of organic phosphate hydrolyzed in stalks of the lotic diatom Didymosphenia geminata and the possible impact of atmospheric and climatic changes
}

\author{
N. T. W. Ellwood · B. A. Whitton
}

Received: 13 February 2007 / Revised: 25 March 2007 / Accepted: 30 March 2007 / Published online: 21 July 2007

(C) Springer Science+Business Media B.V. 2007

\begin{abstract}
The aquatic colonial stalked diatom, Didymosphenia geminata, has acquired notoriety in recent years because of huge increases in many rivers of temperate regions. However, in some streams in northern England it has probably or, in the case of the R. Coquet (Northumberland), certainly been abundant for many decades. The paper describes the nutrient environment and phosphatase activities of Didymosphenia in Stony Gill (N. Yorkshire), a fast-flowing stream draining an upland catchment with peaty soils overlying limestone. Organic phosphate formed $85 \%$ of the filtrable phosphate in the water during the study (January-August 2000), with a maximum in April. Colonies were most abundant in June, but had disappeared by August. Surface phosphomonoesterase (PMEase) and phosphodiesterase activities assayed from March to July showed low PMEase activity in early March, but otherwise both were high throughout the period and especially so in June and July. Use of BCIP-NBT staining proce-
\end{abstract}

Handling editor: L. Naselli-Flores

N. T. W. Ellwood · B. A. Whitton ( $\square)$

School of Biological and Biomedical Sciences,

University of Durham, Durham DH1 3LE, UK

e-mail: b.a.whitton@durham.ac.uk

N. T. W. Ellwood

Dipartimento di Scienze Geologiche, Università

Roma Tre, Largo San Leonardo Murialdo 1, Roma

00146, Italy dure showed that PMEase activity occurred in the stalks. A more detailed study of colony structure and staining with material from the R. Coquet in June 2006 also showed marked PMEase activity, with staining localized in the upper part of the stalks and the cells remaining unstained. It is suggested that organic phosphate is hydrolyzed in the stalk and the inorganic phosphate passes to the cell via a central tube in the stalk. It seems likely that organic phosphate as a major P source is a key factor favouring the success of Didymosphenia. The possible impact of environmental changes in the catchment such as climatic warming, $\mathrm{C}$ loss from peat and atmospheric $\mathrm{N}$ deposition is discussed.

Keywords Organic phosphate $\cdot$ Didymosphenia Stalk, Phosphatase staining · Catchment · Climate change $\cdot$ Atmospheric $\mathrm{N}$ deposition

$\begin{array}{ll}\text { Abbreviations } \\ \text { BCIP-NBT } & \begin{array}{l}\text { 5-bromo-4-chloro-3-indolyl } \\ \text { phosphate-nitroblue tetrazolium } \\ \text { bis-para-nitrophenyl phosphate }\end{array} \\ \text { bis- } p \text { NPP } & \begin{array}{l}\text { Extracellular polymeric substance } \\ \text { EPS }\end{array} \\ \text { FON } & \text { Filtrable organic nitrogen } \\ \text { FOP } & \text { Filtrable organic phosphorus } \\ \text { FRP } & \text { Filtrable reactive phosphorus } \\ \text { HEPES } & N \text {-(2-hydroxyethyl)-piperazine- } N^{\prime} \text { - } \\ & \text { 2-ethanesulphonic acid } \\ p N P & \text { para-nitrophenol }\end{array}$




$\begin{array}{ll}p \text { NPP } & \text { para-nitrophenyl phosphate } \\ \text { Pi } & \text { Inorganic phosphate-P } \\ \text { PMEase } & \text { Phosphomonoesterase } \\ \text { PDEase } & \text { Phosphodiesterase } \\ \text { TIN } & \text { Total inorganic nitrogen } \\ \text { TFN } & \text { Total filtrable nitrogen } \\ \text { TFP } & \text { Total filtrable phosphorus } \\ \text { TN } & \text { Total nitrogen } \\ \text { TP } & \text { Total phosphorus }\end{array}$

\section{Introduction}

The diatom Didymosphenia geminata has gained considerable notoriety in recent years because of rapid increases in many streams and rivers in temperate countries, sometimes becoming sufficiently abundant to have considerable nuisance impact. An indication of the recent interest in this diatom is shown by entries on Google, which rose from about 300 in early 2004 to 17,000 in late 2006. The species was first described from the Faroe Islands in 1819 (Lyngbye, 1819) and the literature until recently has been largely taxonomic or floristic records. Kawecka and Sanecki (2003) summarized the early accounts, where, for instance, it has been described as boreal and alpine (Krammer \& Lange-Bertalot, 1986). Canter-Lund and Lund (1995) state it favours rocky places where there is plenty of water movement, such as turbulent rivers and wave-washed shores of lakes.

During the 1980s there were several accounts of conspicuous growths in rivers of northern Europe, including the upper part of R. Glåma in Norway (Skulberg \& Lillehammer, 1984) and streams in Sweden (Johansson, 1982) and Finland (Kawecka \& Eloranta, 1987). In the case of R. Glåma, the diatom formed a dense cover on boulder surfaces directly facing the current. In rapids which were not ice-covered, it could grow throughout the year. It was abundant in parts of the R. Caragh, $\mathrm{S}-\mathrm{W}$. Ireland, where a considerable amount of fine sand was caught within the colonies (Heuff \& Horkan, 1984); the authors speculated whether Didymosphenia and associated stalked diatoms inside the colonies might accumulate silica(te) from the sand rather than the water column, where silicate concentrations were quite low. It was a common epilith in 1988 in two mountain region lakes in Turkey, one of them a glacial lake free of snow cover for only four months (Şahin, 2001).

Since the 1980s there have been an increasing number of reports of abundant growths, including several rivers in S-E. Poland, such as the R. San and its tributaries (WIOŚ-Jaslo, 1996) and three other tributaries of the Vistula (Kawecka \& Sanecki, 2003). There was also mass development downstream of a recent dam on the R. Dunajec in 2002 (Mrozińska-Broda \& Czerwik-Marcinkowska, 2004), although there is no record for the species in the account of the river by Kawecka and Szczęsny (1984). Records from rivers in other countries in Europe include a recent spread in Serbia and Montenegro (Subakov-Simić et al., 2006).

Among various records for the UK, that for the R. Coquet, Northumberland, N-E. England, is best known. It was abundant in upper stretches of the river in the late 1950s (J. M. Edington, pers. comm. to B.A.W.) and similar growths have been observed every time the river has been visited in summer since 1963 (B.A.W., unpublished data). Conspicuous growths have also occurred in some tributaries draining both peat and limestone in the upper part of the R. Tees catchment (Whitton \& Crisp, 1984), including Harwood Beck, where Rivularia dominates upstream, while Didymosphenia is sometimes abundant slightly further downstream (B.A.W., unpublished data).

A recent conference report on Didymosphenia (Spaulding et al., 2006) included summaries about its occurrence in rivers in other parts of the world. Bothwell et al. (2006) reported observations for Vancouver Island, western Canada. Heavy 'blooms' started to appear in the Heber River in 1988-89 and within five years had spread to 12 catchments on Vancouver Island in pristine rivers previously known to have very low algal biomass. Subsequent studies on the potential impact of solar ultraviolet radiation on Didymosphenia community development proved negative. Several authors at the same conference reported large growths in rivers in the USA, especially western states, including the Kootenai River in 
Montana and Idaho (Eichman et al., 2006) and Rapid Creek in South Dakota (Shearer \& Erickson, 2006). Weilhofer et al. (2006) summarized the results of a presence-absence study of 485 streams in western USA between 2000 and 2003 with respect to a range of environmental features. Regression tree analysis showed that the presence of tundra within the watershed was the major predictor of D. geminata presence. For sites without tundra, watershed disturbance was the major predictor.

In spite of all these studies, it was the finding of mass growths of the alga in New Zealand in 2004 which most stimulated great interest, including many newspaper headlines in New Zealand. Biggs et al. (2006) reported that it had not been recorded from the Southern Hemisphere before finding it in New Zealand in October 2004. The authors concluded it was an alien species in New Zealand with potential for significant environmental effects on indigenous ecosystems. They interpreted the various reports to indicate that a 'variant' of the species had arisen in Vancouver Island and migrated to many rivers in North America, Europe and New Zealand.

In contrast to all these studies, there are several reports of D. geminata becoming less frequent or disappearing altogether. Kawecka and Sanecki (2003) gave several such examples for Poland. For instance it was no longer possible to find it where it had been recorded in $\mathrm{R}$. Dunajec (Siemińska, 1964) and the Bialka Tatrańska, a tributary of the Dunajec (Kawecka, 1965). Disappearance from the last was attributed to changed environmental conditions, mainly eutrophication.

Several of the UK sites with conspicuous Didymosphenia were ones where other benthic algae or mosses are known to show marked surface phosphatase activity at times. Such activity in aquatic phototrophs is usually induced under conditions of moderate $\mathrm{P}$ limitation and hence the rate of activity provides a measure of $\mathrm{P}$ limitation (Jansson et al., 1988; Christmas \& Whitton, 1998a, b; Ellwood et al., 2002; Whitton et al. 2005), though it may sometimes also reflect the fact that the only $\mathrm{P}$ source available is organic (Whitton et al., 1991; Ellwood \& Whitton, 2007). It was therefore planned to compare changes in surface phosphatase activities of Didymosphenia in Stony Gill, North Yorkshire, during the main part of one growth season with concentrations of $\mathrm{N}$ and $\mathrm{P}$ fractions in the water. This relates to a larger (2-year) study on water chemistry and surface phosphatase activities of submerged mosses in four upland fast-flowing streams in northern England (Ellwood et al., in press). In order to confirm observations from this stream, studies were also made on Didymosphenia colonies from R. Coquet.

\section{Sample sites}

Stony Gill (Fig. 1) This is a 4th-order stream within the moorland line of the North Yorkshire Dales National Park, designated an Environmentally Sensitive Area by DEFRA (2002) under its England Rural Development Programme. Catchment soils consist of peat and boulder clay,

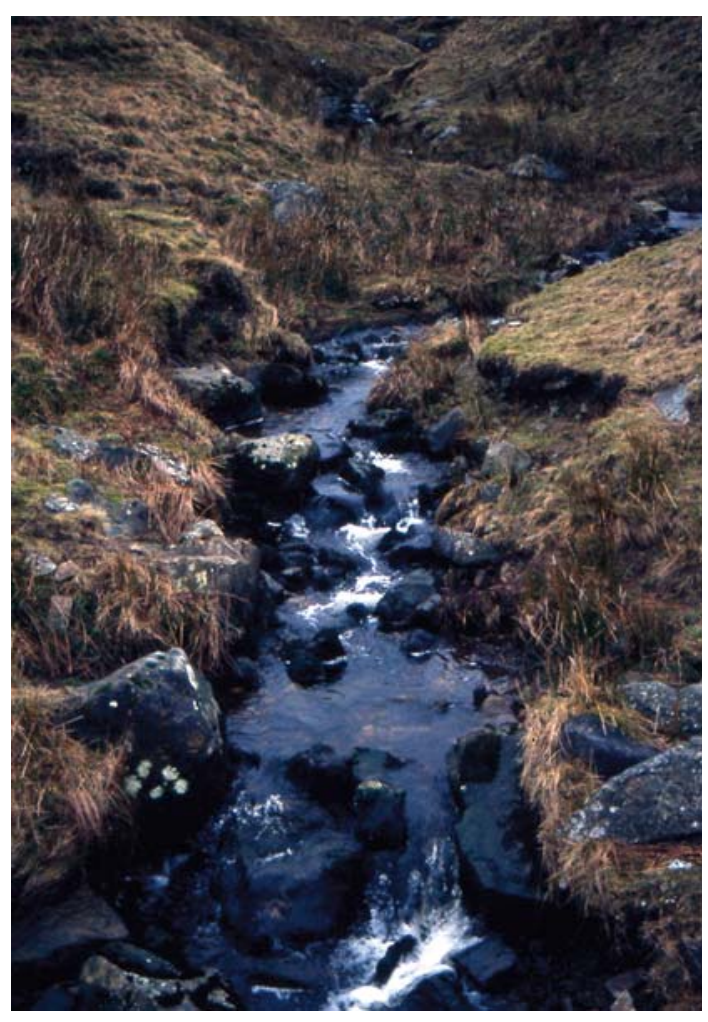

Fig. 1 Stony Gill, showing site with Didymosphenia colonies 
which overlie Carboniferous Limestone. At least in recent years, there has been no fertilization of the $1-\mathrm{km}^{2}$ upstream catchment, although the land is used for sheep grazing.

Sampling was confined within a $10-\mathrm{m}$ reach (542' N, 2॰15' W; NY929964; 375 m.a.s.l.), although Didymosphenia colonies were also obvious for short distances upstream and downstream. The streambed of the reach is typically $1.0 \mathrm{~m}$ wide and $0.15 \mathrm{~m}$ deep and composed of boulders $(10 \%)$, cobbles $(60 \%)$, pebbles $(15 \%)$ and sand/ silt $(15 \%)$. Immediately upstream there is a succession of waterfalls and the water is well oxygenated (Table 1). Flow varies markedly in response to rainfall and there was at least one flow event during the study sufficiently high (Table 1) to have a visually obvious effect on the streambed; $\mathrm{pH}$ decreased to 7.2 at this time.

River Coquet (Fig. 2) The $90-\mathrm{km}$ river is relatively unmodified and important to anglers because of its migratory sea trout and salmon (Alabaster, 1970); diverse organizations have helped to ensure that a high river quality is maintained. The whole river (and some adjacent woodland) was designated a Site of Special Scientific Interest in 1996. Notification of this to the (UK) Secretary of State included the presence of Didymosphenia among the biota quoted to support the case.

The sample site $\left(55^{\circ} 11^{\prime} \mathrm{N} ; 2^{\circ} 10^{\prime} \mathrm{W}\right.$; NT 891063 : 200 m.a.s.l.) and its upstream catchment (approx. $60 \mathrm{~km}^{2}$ ) lie within the Northumberland National Park. This part of the catchment is mostly rough grassland used for low density sheep grazing and only small areas have at times been fertilized. There are also small areas of heather (Calluna vulgaris) moor, which are burnt in winter every

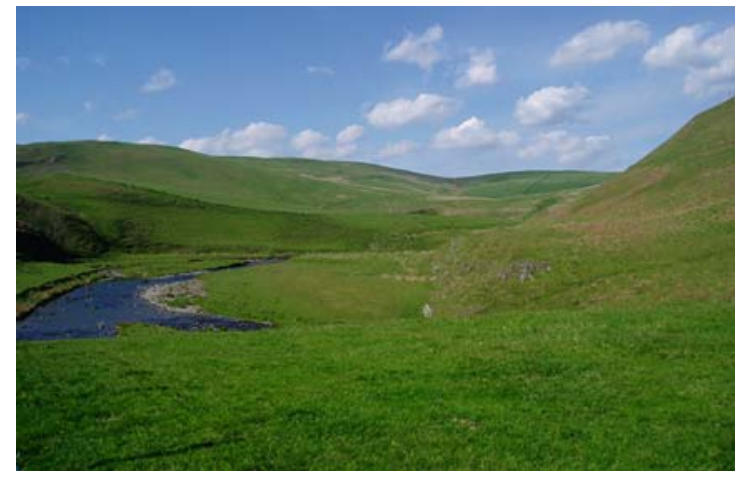

Fig. 2 R. Coquet catchment upstream of main sample site

few years. Water flows rapidly over a substratum of solid rock and large boulders, with some cobbles and pebbles towards the side; there is considerable variation in water depth within the reach. Mean cell dimensions $(n=25)$ of Didymosphenia were: cell length $123 \mu \mathrm{m}$, valve width $47 \mu \mathrm{m}$; girdle width $32 \mu \mathrm{m}$; stalk diameter $19 \mu \mathrm{m}$.

\section{Materials and methods}

\section{Field}

Sampling for water chemistry and other environmental variables was made in Stony Gill at the site used for sampling Didymosphenia twice a month from January to July 2000. Most measurements are a subset of those used in conjunction with a 2-year study of the environment for aquatic mosses (Ellwood et al., in press), so methods are described only briefly here. Temperature and conductivity were measured with a WTW (Wissenschaftliche Technische Werkstätten,

Table 1 Physical and chemical variables in Stony Gill for 2000, based on sampling twice a month, together with mean values for the five months during which phosphatase measurements made

\begin{tabular}{|c|c|c|c|c|}
\hline \multirow[t]{2}{*}{ Variable } & \multicolumn{2}{|c|}{ 12-m period } & \multirow{2}{*}{$\begin{array}{l}\text { Assay period } \\
\text { Max }\end{array}$} & \multirow[b]{2}{*}{ Mean (SD) } \\
\hline & Min & Mean & & \\
\hline Flow $\left(\mathrm{m}^{-3} \mathrm{~s}^{-1}\right)$ & 0.006 & $0.034(0.09)$ & 0.46 & $0.019(0.03)$ \\
\hline Temperature $\left({ }^{\circ} \mathrm{C}\right)$ & 1.4 & $7.7(3.8)$ & 13.7 & $7.5(3.6)$ \\
\hline Conductivity $\left(\mu \mathrm{S} \mathrm{cm}^{-1}\right)$ & 50.0 & $157.8(60.2)$ & 267.0 & $156.1(66.6)$ \\
\hline $\mathrm{PH}$ & 7.0 & $8.0(0.3)$ & 8.4 & $8.0(0.3)$ \\
\hline $\mathrm{O}_{2}(\%)$ & 84 & $100(7.1)$ & 117 & $100.9(6.9)$ \\
\hline
\end{tabular}

For more information on Stony Gill, see Ellwood et al., in press 
Weilheim, Germany) model LF $320 \mathrm{~m}$ with a TetraCon 325 probe. The $\mathrm{pH}$ was measured in the field with a WTW meter (model pH 196 with a WTW SenTix electrode type 41-3). Calibration was performed prior to measurements using the standard BDH pH buffers: 4.0, 7.0, 9.22. Values for mean $\mathrm{pH}$ were determined after antilogarithmic conversion.

Plastics and glassware were soaked in $2 \%(\mathrm{v} / \mathrm{v})$ Decon ${ }^{\circledR}$ (Decon Laboratories Ltd, Hove, UK) solution for at least $24 \mathrm{~h}$ and rinsed four times in deionized water. Water for analysis of dissolved nutrients was passed at the site through $0.45 \mu \mathrm{m}$ cellulose-acetate membranes, (previously soaked in $10 \% \mathrm{HCl}$ and rinsed in deionised water) held in a Millipore Swinnex filter housing. Water for total nutrient analysis was collected in bottles primed with stream water.

Didymosphenia colonies in Stony Gill used for assays were taken from rock surfaces with obvious flow. However, there was only sufficient macroscopically visible material to conduct measurements for five months (March-July 2000). The colonies were washed gently in stream water at the site and again just before conducting assays. During transport to the laboratory, they were stored in a cool box with ice. Preliminary staining studies were made on material collected in early summer.

A further study was made on material sampled from R. Coquet on 4 June 2006. This was used mainly for staining, but a few environmental measurements were made at the time of collection and a phosphatase assay conducted along with the staining. Material from both Stony Gill and R. Coquet corresponded to D. geminata

\section{Analysis}

Ammonia, nitrate and phosphate fractions were analysed using a Skalar San ${ }^{\text {plus }}$ segmented flow analyser (Skalar Analytical, Breda, The Netherlands; 1995). The use of 3 and 5-cm path length cuvettes gave limits of detection of approximately $2 \mu \mathrm{g} \mathrm{L}^{-1}$ for $\mathrm{N}$ and $\mathrm{P}$, respectively. FON, TN, FOP, TP were estimated following alkaline persulphate digestion of filtered and unfiltered samples (Langer \& Hendrix, 1982; Lambert \& Maher, 1994).
Phosphatase assays

Material was kept refrigerated and assayed within $24 \mathrm{~h}$ of collection. Assays were conducted using the methods of Turner et al. (2001) with the analogue substrates $p$ NPP and bis- $p$ NPP. Care was taken to remove obvious detritus from the colonies prior to analysis. Around $10 \mathrm{mg}$ portions of colonies were placed in glass vials containing $2.9 \mathrm{~mL}$ of buffered assay medium (20 mM N-2-hydroxyethylpiperazine- $N^{\prime}-2$ ethanesulphonic acid (HEPES), $\mathrm{pH}$ 8.0). This assay medium was a modification of the No. 10 medium of Chu (1942), with EDTA as a chelator and the absence of $\mathrm{N}$ and P. Assays were initiated by adding $0.1 \mathrm{~mL}$ substrate (100 $\mu \mathrm{M}$ final concentration) and the vials were incubated for $20 \mathrm{~min}$ in a shaking water bath ( $\mathrm{ca}$ 100 strokes $\left.\mathrm{min}^{-1}\right)$ at $20^{\circ} \mathrm{C}$ and low level laboratory light $\left(15-20 \mu \mathrm{mol}\right.$ photon $\left.\mathrm{m}^{-2} \mathrm{~s}^{-1}\right)$. Three replicate assays plus blanks (medium and substrate, no cells) and controls (medium and cells, no substrate) were measured.

To terminate the assay and develop product colour, $2.5 \mathrm{~mL}$ assay mixture was removed immediately and added to $0.25 \mathrm{~mL}$ terminator solution (Fedde \& Whyte, 1990). This step was timed precisely. Following analysis, the material was extracted for chlorophyll a (Stony Gill) or dried at $105^{\circ} \mathrm{C}$ for $24+\mathrm{h}$ and then weighed to $0.00001 \mathrm{~g}$ on a microbalance (R. Coquet).

\section{Phosphomonoesterase staining}

Staining for phosphomonoesterase activity involved the hydrolysis of BCIP-NBT, which produces a blue-purple stain/precipitate at the site of the reaction (Coston \& Holt, 1958), thus locating the enzyme. BCIP-NBT solution in alkaline buffer was used as received from Sigma-Aldrich Chemicals, Poole, UK. Colonies of Didymosphenia were incubated in $4 \mathrm{~mL}$ BCIP-NBT solution at room temperature $\left(\mathrm{c} 20^{\circ} \mathrm{C}\right)$ for around 15-20 min before terminating the reaction with $0.5 \mathrm{M} \mathrm{NaOH}$ and washing with de-ionised water. Termination was required to avoid overdevelopment of the stain. The samples were then observed by microscopy and c 50 images taken as a permanent record. 


\section{Results}

\section{Stream water}

Stony Gill There were obvious changes in nutrient concentrations in Stony Gill during the study period (Fig. 3), with a peak in FOP in late spring. On most occasions FOP markedly exceeded FRP with a mean of $85 \%$ TFP during the period (Fig. 4). Overall, inorganic $\mathrm{N}$ was quantitatively more important than organic $\mathrm{N}$. The ratio of filtrable $\mathrm{N}: \mathrm{P}$ (by mass) was usually high $(>10)$, but there was a period in May-June when this only applied if FON was taken into consideration (Fig. 3).

$R$. Coquet Water chemistry on the sampling day $(1600 \mathrm{~h})$, when flow was relatively low, was: $169 \mu \mathrm{S} \mathrm{cm}^{-1}$, absorbance at $420 \mathrm{~nm}, 0.010 ; \mathrm{pH} 8.6$; TFP, $15 \mu \mathrm{g} \mathrm{L}^{-1}$, TP $21 \mu \mathrm{g} \mathrm{L}^{-1}$, TFN, $371 \mu \mathrm{g} \mathrm{L}^{-1}$; TFN:TFP $=24$; TN:TP $=18$ (by mass). Spot measurements at other times when flow was higher have shown $\mathrm{pH}$ values nearer neutral.

\section{Occurrence}

Stony Gill Didymosphenia colonies were frequent and locally abundant in the reach and also some distance upstream and downstream during spring and summer visits in (at least) the late 1990s as well as the period of the present study. However, no colonies or individual cells were found in benthic algal films in late May or July 2006 at this site or several hundred metres upstream and downstream.

Colonies of Didymosphenia were frequent during late winter and early spring 2000, though phosphatase measurements only commenced in March. By late spring there were abundant colonies, reaching a peak in June. In July there was a visible reduction in cover, although colonies were still abundant. However, it proved impossible to find colonies on the first sampling in August (17th).

The development of colonies on more stable substrata, in fast- and slow- moving sections, formed mats $1-2 \mathrm{~cm}$ thick. During the period of maximum cover, there was also abundant growth on less stable substrata, including epiphytic on aquatic mosses; at this time the Didymosphenia cover at the site was about $60-70 \%$ of the streambed.

In addition to epiphytic bacteria, the colonies included some other diatoms (Amphora, Tabellaria,
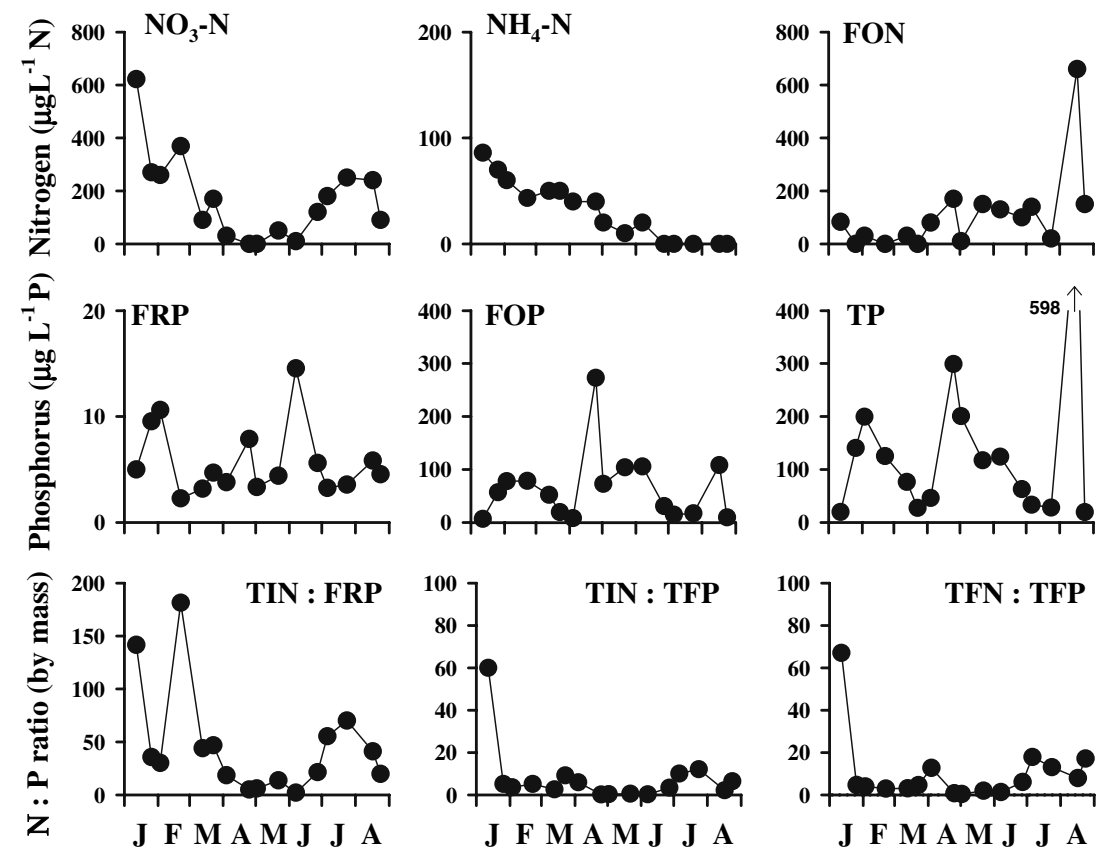

Fig. 3 Changes in aqueous nitrogen and phosphorus fractions in Stony Gill during January-August 2000, together with changes in the ratios between various fractions. For guide to Abbreviations, see main list 


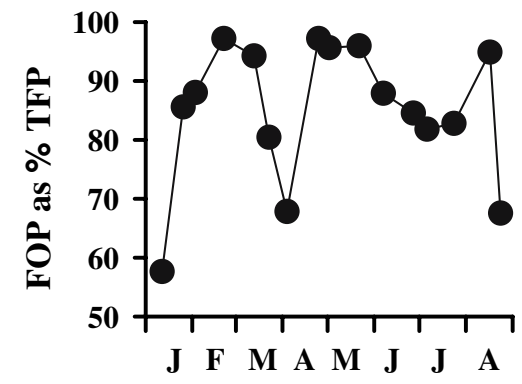

Fig. 4 Changes in FOP as \%. TFP from January to August 2006. FOP, filtrable organic P; TFP, total filtrable P

motile naviculoids and epiphytic Achnanthidium minutissimum), together with occasional narrow sheathed cyanobacteria.

$R$. Coquet Colonies were abundant on rock surfaces, mostly just below the surface of the water; common on flattish rocks just below water surface with fast current.

Phosphatase assays

Stony Gill PMEase activity increased during the study period, whereas PDEase decreased initially, but then increased broadly in parallel with PMEase activity (Fig. 5). The ratio of PDEase to PMEase activity was therefore much higher at the beginning than during the rest of the study. For the $R$. Coquet PDEase:PMEase was 0.42 .

\section{Staining}

Stony Gill A preliminary study with BCIP-NBT on colonies from Stony Gill in early summer showed marked staining of the upper part of the stalks. Some of the associated organisms also showed staining, but, even when considered together, this was much less than shown by the Didymosphenia stalks. It had been hoped to follow this with a more intensive study on Stony Gill colonies, but their absence in 2006 led to a switch to the R. Coquet.

$R$. Coquet The stalks supporting most cells had branched about four times (Fig. 6). Staining results can be summarized as:

1. The uppermost branch of most stalks showed obvious staining and sometimes also the stalk section below, though usually less intensely (Fig. 7a). In such cases the junction between the two sections usually stained more than the adjacent parts of the stalk. The lowermost parts of the main stalk never showed staining.

2. Staining was particularly intense immediately below the cell, especially when cells were dividing and a new branch forming (Fig. 7b).

3. Staining appeared to be inside the stalks rather than localized on the stalk surface

4. The cell surface showed no staining (Fig. 7b).

5. Each stalk had what appears to be a central tube (c $2 \mu \mathrm{m}$ diameter), which extended further down the stalk than the stained region (Fig. 7c). The wall of the tube did not show obvious staining, but it proved difficult to decide whether or not staining reached the inside of the tube.

\section{Discussion}

The results indicate that organic phosphate is the main form of phosphate in the stream, that Didymosphenia colonies show high phosphatase
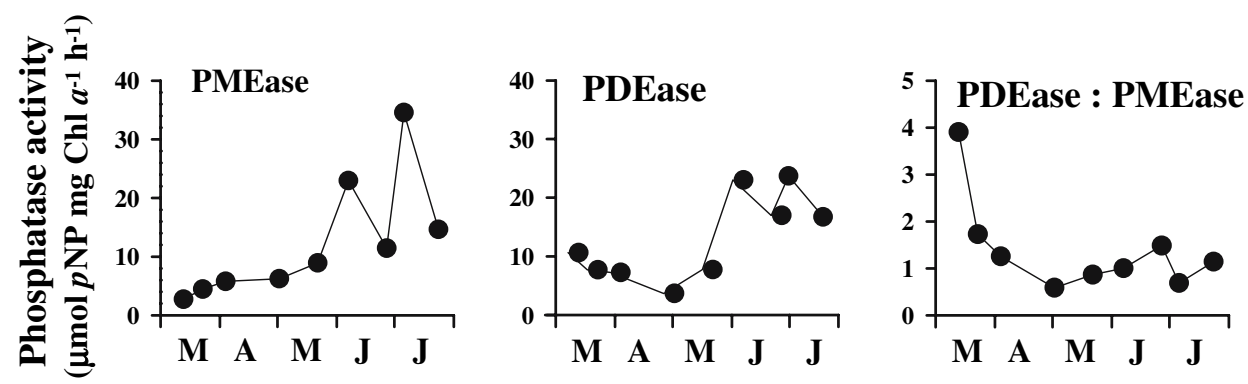

Fig. 5 Changes in PMEase and PDEase activities in Stony Gill during March-July 2000, together with ratio between PDEase and PMEase. PMEase, phosphomonoesterase; PDEase, phosphodiesterase 


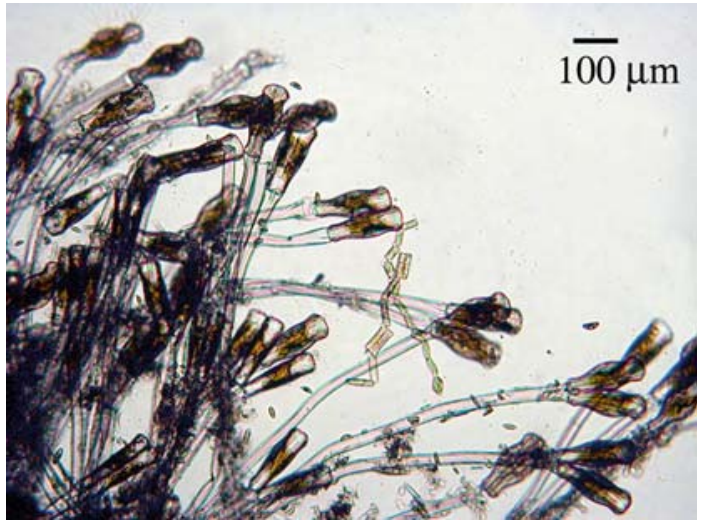

Fig. 6 Upper part of Didymosphenia colony from R. Coquet on 4 June 2006

activity when assayed with analogue substrates and that this activity is localized in the stalks. In view of the importance of these observations for assessing the ecology of the diatom, each will be considered in more detail.

FOP averaged $85 \%$ TFP during the period when phosphatase measurements were made (Fig. 4) and the value was quite similar over a 2-year period (Ellwood et al., in press). Based on observations for individual days, it exceeded this value for $70 \%$ of the time and in May approached $100 \%$. By far the highest absolute value corresponded to the highest flow. The evidence for other upland streams in northern England also suggests that high FOP is associated with high flow events (Livingstone \& Whitton, 1984; Turner et al., 2003). It therefore seems likely that short periods of high flow provide the optimum conditions for supply of FOP.

Assays on colony phosphatase included a range of associated organisms and staining showed that some, but not all, other organisms had obvious activity. However, this was minor in comparison with stalks when viewed on a field sample and even more so when related to washed colonies. It therefore seems fair to conclude that the diatom was responsible for at least $90 \%$ activity shown in assays (Fig. 5) and probably more. Both chlorophyll a and dry weight were tested as a measure of biomass, but it was concluded that chlorophyll a is more suitable, even though it was the stalk, not the cell, which was responsible for the measured activity. Based on this, the rates may be considered quite high in comparison with other aquatic phototrophs (Whitton et al., 2005).

PMEase activity of the R. Coquet was largely restricted in the upper part of the branched stalk, though extended further down the stalk (not as far as the base) in the sample tested from Stony Gill. Although there is no comparable staining technique for PDEase activity, enzyme assays on other phototrophs (Whitton et al., 2005) suggest the likelihood that both activities are located in similar regions of the organism. This raises several questions. How does the phosphate released by hydrolysis reach the diatom cell?
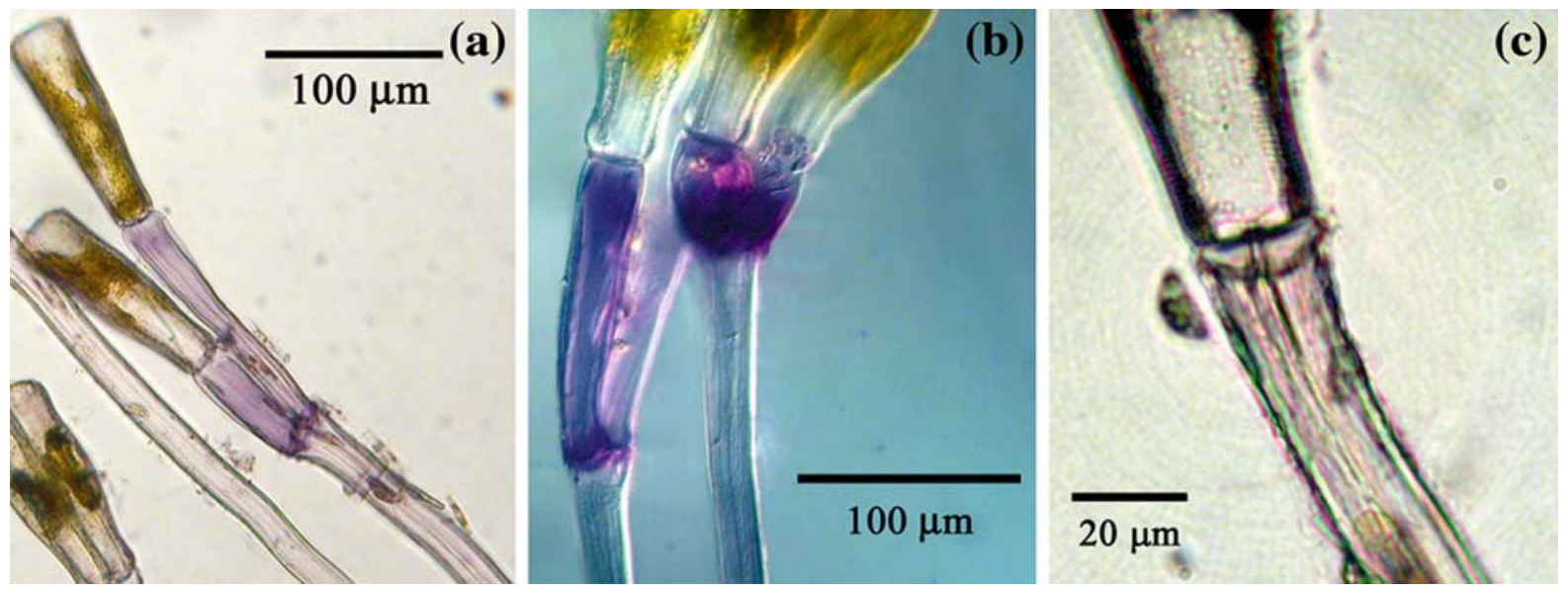

Fig. $7 \mathbf{a}, \mathbf{b}, \mathbf{c}$. Use of BCIP-NBT stain with R. Coquet colonies showing localization of PMEase activity on upper regions of the stalks, but not on cells. Unstained stalk showing central tube. For guide to Abbreviations, see main list 
Perhaps it occurs by diffusion in the tube-like structure in the middle of the stalk, followed by active uptake by the cell. To what extent are other processes taking place in or between the stalks inside an individual colony important for success of that colony? Do the stalks of other diatoms behave in a similar way? Preliminary observations by Gretz et al. (2006) suggest that stalks of D. geminata resemble those of Cymbella cistula in being composed primarily of a sulphated xylogalactan, which is intrinsically hydrophilic, with ionic cross-bridging indicated.

Comparisons of $\mathrm{N}$ and $\mathrm{P}$ fractions in Stony Gill water (Fig. 3) show marked differences in the ratio of the two, whether or not FON and FOP are considered. The ratios, TIN:FRP and TFN:TFP, were sufficiently low in May and June to suggest that the ability of the diatom to use FON as an important $\mathrm{N}$ source/should be investigated. However, even if the stalks have a role in this, it seems more likely that FON breakdown occurs within the cell.

There are apparently no other reports on phosphatases in diatom or any other algal stalks, but there are reports of bacterial stalks increasing markedly in response to phosphate limitation. Schmidt and Stanier (1966) describe this for several species. The most detailed account (Ireland et al., 2002) is for the bacterium Caulobacter crescentus, which is widespread in oligotrophic waters and for which the complete genome sequence is known. Here the stalk is an extension of the cell membrane and stalk elongation is stimulated by phosphate starvation. The authors recognized 39 different proteins in the stalk, including two alkaline phosphatases and a 3-phytase. These phosphatases and several other proteins which were present fit the hypothesis that the stalks play a role in nutrient uptake.

Didymosphenia stalks may also be compared with the multicellular hairs of various cyanobacterial genera and a few genera in most of the major eukaryotic algal taxa forming multicellular thalli (Whitton, 1988). In all cases hairs form in response to phosphate limitation and they are the main, though usually not the only, site of surface phosphatase activities (Whitton et al., 2005). Two of the genera studied in most detail, Rivularia (Whitton, 1987) and Stigeoclonium (Gibson \&
Whitton, 1987a, b) can sometimes dominate upland streams in northern England combining drainage from peaty soils and usually calcareous rock. The life cycle of both Rivularia and upland Stigeoclonium depends on a period of much higher phosphate concentrations in spring being followed by subsequent periods with lower phosphate, but Stony Gill did not show such clear-cut seasonal changes during a 2-yr survey (Ellwood et al., in press). In view of the fact that Didymosphenia now appears to have disappeared from this stream, studies are needed on annual changes in aqueous phosphate in streams where Didymosphenia remains abundant from year to year.

As many other cyanobacteria and eukaryotic algae have surface phosphatases and can utilize organic phosphates without developing stalks or hairs (Whitton et al., 2005), it is unclear what the advantages are of localizing activity on only part of the organism. Possibilities to be considered are whether the large surface area not only provides more contact with the environment, but helps to optimize uptake from transient periods of high FOP or enzymic hydrolysis of the more recalcitrant forms of organic phosphate. The mucilaginous EPS formed by some cyanobacteria lacking the ability to form hairs in response to phosphate limitation sometimes includes immobilized PMEase (Whitton et al., 2005). There are reports of increasing and changing composition of diatom EPS in response to environmental stress, such as in Cylindrotheca closterium (Apoya-Horton et al., 2006), but apparently none specifically resulting from phosphate limitation.

Stony Gill and other streams in northern England where abundant Didymosphenia growth is known to the authors, such as several tributaries of the R. Eden, Cumbria, all drain catchments with peaty soils and calcareous rock. Their water tends to be rich in humic materials when flow is high following rainfall and with less humic materials, but much harder, when flows are low. Here the peaty soils are almost certainly the main source of organic phosphate in the water. However, Didymosphenia is sometimes abundant in rivers with much softer water, such as R. Glåma in Norway (Skulberg \& Lillehammer, 1984). Any influence of intermittently hard water is presumably a direct or indirect effect of high $\mathrm{Ca}$, and not 
high $\mathrm{Mg}$, since Harwood Beck drains metamorphosed limestone with very low $\mathrm{Mg}$ content (Whitton \& Crisp, 1984; Livingstone \& Whitton, 1984).

Effective world-wide management requires an understanding of why striking increases have occurred in some countries. When the results for individual rivers and streams, together with the statistical study of Weilhofer et al. (2006) in the USA showing the importance of tundra in the catchment and catchment disturbance elsewhere, are considered in relation to the present study. It seems probable that its release from peat or peaty soils in late winter or spring is a key factor. Recent Didymosphenia increases might simply be due to catchment disturbance, but we suggest that climate and other environmental changes may be important. Rising temperature may lead to an increased rate of peat breakdown, with loss of $\mathrm{CO}_{2}$ and release of organic compounds including FOP to streams, with the effect being enhanced by atmospheric $\mathrm{N}$ deposition (Bragazza et al., 2006). These authors concluded that increased atmospheric $\mathrm{N}$ deposition led to enhanced microbial activity in the peat, as shown by PMEase and $\beta$-glucosidase activities. We suggest that, at least in the short-term, changes in peat due to atmospheric $\mathrm{N}$ deposition may be as, if not more, important in influencing the chemistry of drainage streams, than changes due to temperature increase. Within the streams the changes in phosphate composition, amount and seasonality may prove more important to many phototrophs in otherwise unpolluted streams than relatively small increases in water temperature.

Didymosphenia has been treated as an invader to New Zealand as a result of the finding of mass growths in 2004 (Biggs, 2006) and research and control appear to be based on this assumption. Aquatic systems in New Zealand have suffered greatly as a consequence of vascular plant invaders (Howard-Williams et al., 1987), but the evidence that Didymosphenia is an invader rests on the lack of previous records and the fact that huge growths have appeared in rivers where there were none previously. However, even if the species were an invader, it must have been introduced well before 2004 for such huge growths to occur in different rivers, yet it went unnoticed in surveys.
One possibility is that strains, which have adapted over several centuries to man-induced changes in Europe, have recently invaded and adapted to local conditions elsewhere. Probably the only way to establish the extent to which the species is an invader in some countries is by very detailed molecular comparison of populations round the world. A recent study by Carter (in press) emphasizes the need for caution. He found a D. geminata cell associated with the floating liverwort Ricciocarpus natans in a small highly calcareous pond in Northamptonshire, a lowland area of southern England, which appears superficially a very different habitat from the others described. Nevertheless, organic phosphate is likely to be an important $\mathrm{P}$ source in such a water body at some times of year, so perhaps Didymosphenia occurs in other habitats than those for which it is best known. The converse possibility that this is a sign of Didymosphenia invading a new habitat can of course not be ruled out.

While Didymosphenia has invaded many rivers in recent years, in some such as the R. Coquet it has been abundant for many years. In other cases populations appear to vary a lot from year to year, but detailed studies are lacking. However, it is known that cells may be removed by high levels of suspended material, while the stalks persist, as shown by observations in an inflow stream to Lough Inagh, Connemara, Ireland, between May and June 2006 (D. M. John and B. A. Whitton, unpublished data). The possible roles of upstream sources of inocula and of in situ factors such as the effects of floods on colonies with a heavy epiphyte load and hence increased drag are uncertain. However, in the case of Stony Gill it is difficult to suggest a convincing hypothesis why the alga disappeared from the site between July and August 2000, nor why it appeared to have disappeared altogether by summer 2006 .

Understanding the factors leading to short- or long-term decreases or complete disappearance would aid the development of control measures. One possible explanation for decreases in Didymosphenia population is a shift from organic towards inorganic phosphate in the water, since this might give a competitive advantage to nonstalked diatoms and other algae, which might in turn provide a better food for grazers. Another 
possibility is that in situ strains of non-stalked species adapt to make more efficient use of organic phosphate or are replaced by better adapted strains from other sites. Similarly, grazers more effective at grazing Didymosphenia might replace the original grazers.

In conclusion, important factors favouring mass growths of Didymosphenia in fast-flowing streams and rivers appear to include climate change and/or deposition of high levels of atmospheric $\mathrm{N}$, release of organic phosphate from peat- or other organic-rich soils to the water and the absence of pollution from other sources, especially input of inorganic phosphate. A moderately hard water seems to be another contributory factor in some regions, but its overall importance is unclear. Other factors whose importance is equally unclear are seasonal changes in rainfall and their impact on the input of organic phosphate and the mechanical removal of colonies by scour, both of which are likely to influence the seasonal growth cycle at a site.

Acknowledgements NTWE was supported by a studentship from the UK Engineering and Physical Sciences Research Council during the first part of the study. The authors are most grateful to Prof. Patrizia Albertano (Dipartimento di Biologia, Universita degli Studi di Roma "Tor Vergata", Rome, Italy) for use of laboratory facilities. We also appreciate helpful discussions with Dr Max L. Bothwell (National Hydrology Institute, Saskatoon, Canada), Prof. Barbara Kawecka (Institute of Nature Conservation, Polish Academy of Sciences, Kraków, Poland), Dr Martyn G. Kelly (Bowburn Consultancy, Co. Durham, UK) and Dr R. Baxter (University of Durham).

\section{References}

Alabaster, J., 1970. River flow and upstream movement and catch of migratory salmonids. Journal of Fish Biology 2: 1-13.

Apoya-Horton, M. D., L. Yin, G. J. C. Underwood \& M. R. Gretz, 2006. Movement modalities and responses to environmental changes of the mudflat diatom Cylindrotheca closterium (Bacillariophyceae). Journal of Phycology 42: 379-390.

Biggs, B. J. F., C. Kilroy \& C. C. Vieglais, 2006. A New Zealand science response to help manage Didymosphenia geminata-an unwanted diatom invader of freshwaters. In Spaulding, S., R. Wiltshire \& L. Elwell (eds), (conference organizers) Current Knowledge of Didymosphenia geminata: Developing a Research and
Management Response. Federation of Fly Fishers and EPA Region 8, held in association with Western Division American Fisheries Society Annual Meeting, May 15-16: 2006, Montana State University, Montana, USA, 29 pp., p.7.

Bothwell, M. L., D. M. J. Sherbot, J. Denisgeger, H. Wright, D. Lynch \& D. J. Kelly, 2006. Blooms of Didymosphenia geminata in rivers of Vancouver Island. 1990 to present: a sign of environmental change or a new invasive species? In Spaulding, S., R. Wiltshire \& L. Elwell, (conference organizers). Current Knowledge of Didymosphenia geminata: Developing a Research and Management Response. Federation of Fly Fishers and EPA Region 8, held in association with Western Division American Fisheries Society Annual Meeting, May 15-16: 2006, Montana State University, Montana, USA, 29 pp., p.9.

Bragazza, L., C. Freeman, T. Jones, H. Rydin, J. Limoens, N. Fenner, T. Ellis, R. Gerdol, M. Hájek, T. Hájek, P. Iacumin, L. Kutnar, T. Tahvanainen \& H. Toberman, 2006. Atmospheric nitrogen deposition promotes carbon loss from peat bogs. PNAS 103(51): 19386 19389.

Canter-Lund, H. \& J. W. G. Lund, 1995. Freshwater Algae. Their Microscopic World Explored. Biopress, Bristol, UK, pp. 360.

Carter, C. F., in press Didymosphenia geminata (Lyngbye) M. Schmidt in a non-typical environment. Quekett Journal of Microscopy.

Christmas, M. \& B. A. Whitton, 1998a. Phosphorus and aquatic bryophytes in the Swale-Ouse river system, north-east England. 1. Relationship between ambient phosphorus, internal N:P ratio and surface phosphatase activity. Science of the Total Environment 210/ 211: 389-399.

Christmas, M. \& B. A. Whitton, 1998b. Phosphorus and aquatic bryophytes in the Swale-Ouse river system, north-east England. 2. Phosphomonoesterase and phosphodiesterase activities of Fontinalis antipyretica. Science of the Total Environment 210/211: 401-409.

Chu, S. P., 1942. The influence of the mineral composition of the media on the growth of planktonic algae. 1 . Methods and culture media. Journal of Ecology 30: 284-325.

Coston, S. \& S. J. Holt, 1958. Kinetics of aerial oxidation of indolyl and some of its halogen derivatives. Proceedings of the Royal Society of London, Series B 148: 506-510.

DEFRA (Department for Environment, Food and Rural Affairs), 2002. Rural affairs. England Rural Development Programme 2000-2006. MAFF 2000; PB5298.

Eichman, J. K., C. Holderman \& G. T. Lester, 2006. Didymosphenia geminata and the periphyton community of the Kootenai River, Montana and Idaho. In Spaulding, S., R. Wiltshire \& L. Elwell (conference organizers) Current Knowledge of Didymosphenia geminata: Developing a Research and Management Response. Federation of Fly Fishers and EPA Region 8 , held in association with Western Division American Fisheries Society Annual Meeting, May 15-16: 2006, 
Montana State University, Montana, USA. 29 pp., p.11.

Ellwood, N. T. W., S. M. Haile \& B. A. Whitton, 2002. Surface phosphatase activity of the moss Warnstorfia fluitans as an indicator of the nutrient status of an acidic stream. Verhandlung Internationale Vereinigung Limnologie 28: 620-623.

Ellwood, N. T. W., S. M. Haile \& B. A. Whitton, in press. Aquatic plant nutrients, moss phosphatase activities and tissue composition in four upland streams in northern England. Journal of Hydrology.

Ellwood, N. T. W. \& B. A. Whitton, 2007. Phosphatase activities of the aquatic moss Warnstorfia fluitans (Hedw.) Loeske from an acidic stream in North-East England. Hydrobiologia 575: 96-107.

Fedde, K. N. \& M. P. Whyte, 1990. Alkaline phosphatase (tissue-non specific isoenzyme) is a phosphoethanolamine and pyridoxal-5'phosphate ectophosphatase: normal and hypophosphatasia fibroblast study. American Journal of Human Genetics 47: 767-775.

Gibson, M. T. \& B. A. Whitton, 1987a. Hairs, phosphatase activity and environmental chemistry in Stigeoclonium, Chaetophora and Draparnaldia (Chaetophorales). British Phycological Journal 22: 11-22.

Gibson, M. T. \& B. A. Whitton, 1987b. Influence of phosphorus on morphology and physiology of freshwater Chaetophora, Draparnaldia and Stigeoclonium (Chaetophorales, Chlorophyta). Phycologia 26: 59-69.

Gretz, M. R., M. L. Riccio, T. R. Hungwe, H. M. Burger, S. N. Kiemle, M. D. Apoya \& S. A. Spaulding, 2006. Extracellular polymers of the stalked diatom Didymosphenia geminata. In Spaulding, S., R. Wiltshire \& L. Elwell, (conference organizers) Current Knowledge of Didymosphenia geminata: Developing a Research and Management Response. Federation of Fly Fishers and EPA Region 8, held in association with Western Division American Fisheries Society Annual Meeting, May 15-16: 2006, Montana State University, Montana, USA. 29 pp., p. 13.

Heuff, H. \& K. Horkan, 1984, Caragh. In Whitton, B. A. (ed.) Ecology of European Rivers. Blackwell, Oxford: 644 pp, pp 363-384.

Howard-Williams, C., J. S. Clayton, B. T. Coffey \& I. M. Johnstone, 1987. Macrophyte invasions. In Viner, A. B. (ed.), Inland Waters of New Zealand. DSIR Bulletin, Wellington, New Zealand: 494 pp., pp. 307-331.

Ireland, M. E., J. A. Kerby, E. M. Quardokus, J. P. Reilly \& Y. V. Brun, 2002. Proteomic analysis of the Caulobacter crescentus stalk indicates competence for nitrient uptake. Molecular Microbiology 45: 1029-1041.

Jansson, M., H. Olsson \& K. Pettersson, 1988. Phosphatases; origin, characteristics and function in lakes. Hydrobiologia 170: 157-175.

Johansson, C., 1982. Attached algal vegetation in running waters of Jämtland, Sweden. Acta Phytogeographica Suecica 71: 1-84.

Kawecka, B., 1965. Communities of benthic algae in the River Białka and its Tatra tributaries the Rybi Potok and Rostoka. Komitet Zagosp. Ziem. Górskich PAN, 13: 113-129.
Kawecka, B. \& P. Eloranta, 1987. Communities of sessile algae in ssome small streams of centrla Finland. Comparison of the algae of the high mountains of Europe and those of its northern regions. Acta Hydrobiologica 29: 403-415.

Kawecka, B. \& J. Sanecki, 2003. Didymosphenia geminata in running waters of southern Poland - symptoms of change in water quality? Hydrobiologia 495: 193-201.

Kawecka, B. \& B. Szczęsny, 1984. Dunajec. In Whitton, B. A. (ed.), Ecology of European Rivers. Blackwell, Oxford: 644 pp, pp 499-525.

Krammer, K. \& H. Lange-Bertalot, 1986-1991. Bacillariophyceae. Süsswasserflora von Mitteleuropa 2(1-4). VEB G. Fischer Verlag, Jena, Germany.

Lambert, D. \& W. Maher, 1994. An evaluation of the efficiency of the alkaline persulphate digestion method for the determination of total phosphorus in turbid waters. Water Research 29: 7-9.

Langer, C. L. \& P. F. Hendrix, 1982. Evaluation of a persulphate digestion method for particulate nitrogen and phosphorus. Water Research 16: 1451-1454.

Livingstone, D. \& B. A. Whitton, 1984. Water chemistry and phosphatase activity of the blue-green alga Rivularia in Upper Teesdale streams. Journal of Ecology 72: 405-421.

Lyngbye, H. C., 1819. Tentamen Hydrophytologiae Danicae. Hafniae.

Mrozińska-Broda, T. \& J. Czerwik-Marcinkowska, 2004. Eucaryotic algae and cyanobacteria in the River Dunajec upstream and downstream from the new dam reservoirs in Czorsztyn and Sromowce and their use for monitoring. Oceanological and Hydrological Studies 33: 83-98.

Şahin, B., 2001. Epipelic and epilithic algae of Dağbaşi Lake (Rize-TURKEY). Turkish Journal of Botany 25: 187-194.

Schmdt, J. M. \& R. Y. Stanier, 1966. The development of cellular stalks in bacteria. Journal of Cell Biology 28: 5011-5026.

Shearer, J. \& J. Erickson, 2006. Didymosphenia geminata and the rapid creek brown trout fishery, South Dakota. In Spaulding, S., R. Wiltshire \& L. Elwell (conference organizers) Current Knowledge of Didymosphenia geminata: Developing a Research and Management Response. Federation of Fly Fishers and EPA Region 8, held in association with Western Division American Fisheries Society Annual Meeting, May 15-16: 2006, Montana State University, Montana, USA, 29 pp., p. 22.

Siemińska, J., 1964. Chrysophyta 2. Bacillariophyceae Okrzemskie. In Starmach, K (eds), Flora Słodkowodna Polski 6. PWN, Warszawa, 609 pp.

Skalar, 1995. The San ${ }^{\text {plus }}$ Segmented Flow Analyser: Soil and Plant Analysis. Instruction Manual: Publ. No. 0102003. Skalar Analytical, Breda, The Netherlands.

Skulberg, O. \& A. Lillehammer, 1984. Glåma. In Whitton, B. A. (ed.), Ecology of European Rivers. Blackwell, Oxford, 644 pp, pp 469-498.

Spaulding, S., R. Wiltshire \& L. Elwell, 2006. (conference organizers). Current Knowledge of Didymosphenia geminata: Developing a Research and Management 
Response. Federation of Fly Fishers and EPA Region 8, held in association with Western Division American Fisheries Society Annual Meeting, May 15-16: 2006, Montana State University, Montana, USA, 29 pp.

Subakov-Simić, G., M. Cvijan \& S. Cado, 2006. The range spreading of Didymosphenia geminata (Lyngb.) M. Schmidt in the waters of Serbia (Serbia and Montenegro, Europe). In Spaulding, S., R. Wiltshire \& L. Elwell (conference organizers) Current Knowledge of Didymosphenia geminata: Developing a Research and Management Response. Federation of Fly Fishers and EPA Region 8, held in association with Western Division American Fisheries Society Annual Meeting, May 15-16: 2006, Montana State University, Montana, USA, 29 pp., p.24.

Turner, B. L., R. Baxter, N. T. W. Ellwood \& B. A. Whitton, 2001. Characterization of the phosphatase activities of mosses in relation to their environment. Plant Cell and Environment 24: 1165-1176.

Turner, B. L., R. Baxter, N. T. W. Ellwood \& B. A. Whitton, 2003. Seasonal phosphatase activities of mosses from Upper Teesdale, northern England. Journal of Bryology 25: 203-214.

Weilhofer, C. L., S. Spaulding \& Y. Pan, 2006. Habitat characterization of Didymosphenia geminata in the western US. In Spaulding, S., R. Wiltshire \& L. Elwell (conference organizers). Current Knowledge of Didymosphenia geminata: Developing a Research and Management Response. Federation of Fly Fishers and
EPA Region 8, held in association with Western Division American Fisheries Society Annual Meeting, May 15-16: 2006, Montana State University, Montana, USA, 29 pp., p. 26.

Whitton, B. A., 1987. The biology of Rivulariaceae. In Fay, P. \& C. Van Baalen (eds), The Cyanobacteria-A Comprehensive Review. Elsevier, Amsterdam: 543 pp., pp. 513-534. .

Whitton, B. A., 1988. Hairs in eukaryotic algae. In Round, F. E. (ed.), Algae and the Aquatic Environment Contributions in Honour of J.W.G. Lund. Biopress, Bristol, 460 pp., pp. 446-460.

Whitton, B. A., A. M. Al-Shehri, N. T. W. Ellwood \& B. L. Turner, 2005. Ecological aspects of phosphatase activity in cyanobacteria, eukaryotic algae and bryophytes. In Turner, B. L., E. Frossard \& D. S. Baldwin (eds), Organic Phosphorus in the Environment. CAB International, Wallingford, UK, pp. 205-241.

Whitton, B. A. \& D. T. Crisp, 1984. Tees. In Whitton, B. A. (ed.), Ecology of European Rivers. Blackwell, Oxford: 644 pp, pp 145-178.

Whitton, B. A., S. L. J. Grainger, G. R. W. Hawley \& J. W. Simon, 1991. Cell-bound and extracellular phosphatase activities of cyanobacterial isolates. Microbial Ecology 21: 85-98.

WIOŚ-Jasło, 1996. Raport o stanie Środowiska w Województwie Podkarpackim. (The State of the Environment: Report in Subcarpathian Voivodeship). 